NUREG/CR-4658

PNL-5910

RZ

\title{
Aerosols Generated By Spills of Viscous Solutions and Slurries
}

NUREG/CR--4658

TI87 003990

Manuscript Completed: November 1986

Date Published: December 1986

Prepared by

M. Y. Ballinger, W. H. Hodgson

Pacific Northwest Laboratory

Richland, WA 99352

\section{Prepared for}

Division of Fuel Cycle and Material Safety

Office of Nuclear Materials Safety and Safeguards

U.S. Nuclear Regulatory Commission

Washington, DC 20555

NRC FIN B2481

\section{DISCLAIMER}

This report was prepared as an account of work sponsored by an agency of the United States Government. Neither the United States Government nor any agency thereof, nor any of their employees, makes any warranty, express or implied, or assumes any legal liability or responsibility for the accuracy, completeness, or usefulness of any information, apparatus, product, or process disclosed, or represents that its use would not infringe privately owned rights. Reference herein to any specific commercial product, process, or service by trade name, trademark, manufacturer, or otherwise does not necessarily constitute or imply its endorsement, recommendation, or favoring by the United States Government or any agency thereof. The views and opinions of authors expressed herein do not necessarily state or reflect those of the United States Government or any agency thereof. 


\section{ABSTRACT}

Safety assessments and environmental impact statements for nuclear fuel cycle facilities require an estimate of potential airborne releases caused by accidents. Aerosols generated by accidents are being investigated by Pacific Northwest Laboratory to develop methods for estimating source terms from these accidents. Experiments were run by spilling viscous solutions and slurries to determine the mass and particle-size distribution of the material made airborne. In all cases, $1 \mathrm{~L}$ of solution was spilled from a height of $3 \mathrm{~m}$.

Aqueous solutions of sucrose ( 0 to $56 \%$ ) gave a range of viscosities from 1.3 to $46 \mathrm{cp}$. The percent of spill mass made airborie from the spills of these solutions ranged from 0.001 to 0.0001 . The mass of particles made airborne decreased as solution viscosity increased.

Slurry loading ranged from 25 to $51 \%$ total solids. The maximum source airborne $(0.0046 \mathrm{wt} \%)$ occurred with the slurry that had the lightest loading of soluble solids. The viscosity of the carrying solution also had an impact on the source term from spilling slurries.

The effect of surface tension on the source term was examined in two experiments. Surface tension was halved in these spills by adding a surfactant. The maximum weight percent airborne from these spills was 0.0045 , compared to 0.003 for spilils with twice the surface tension.

The aerodynamic mass medium diameters for the aerosols produced by spills of the viscous solutions, slurries, and low surface tension liquids ranged from 0.6 to $8.4 \mu \mathrm{m}$, and the geometric standard deviation ranged from 3.8 to 28.0 . 
Pacific Northwest Laboratory conducted experiments to measure aerosols generated by spills of sucrose solutions, slurries, and low surface tension solutions. Earlier work measured releases from spills of powders and liquids and reported on the mass and particle size of the airborne material. The mass of liquid made airborne depended on spill height and source size. The experiments reported here examined the effect of the varying composition of the solution by spilling liquids of varying viscosity (sucrose concentrations), slurry loadings, and surface tension.

The mass airborne and particle-size distribution of the spills were measured for each loading. Sucrose solutions ranged from 0 to $56 \%$ sucrose and contained $17 \mathrm{~g} / \mathrm{L}$ uranine with corresponding viscosities of 1.3 to $46 \mathrm{cp}$. Slurries were composed of varying amounts of $\mathrm{TiO}_{2}$, glass frit, uranine, and sucrose. One-liter liquid sources were placed in a container and spilled from a height of $3 \mathrm{~m}$. Spills were made in the Radioactive Aerosol Release Tank (RART), which has a volume of $20 \mathrm{~m}^{3}$ (about the size of a small room). The airborne material was collected by high-volume samplers. Particle-size distributions were calculated from samples collected using a high-volume cascade impactor.

The fraction of mass made airborne for the spills of sucrose solutions decreased as sucrose loading and viscosity increased. The greatest amount airborne from solutions containing sucrose was 0.001 wt\% from a $22 \%$ sucrose solution.

Contrary to expectations, the greatest weight percent airborne from slurry spills was 0.005 and occurred with one of the highest loaded slurries $(500 \mathrm{~g} / \mathrm{L}$ solids). A closer examination of the effect of each loading constituent revealed that this slurry was the only one without sucrose added as a thickener to increase solid particle suspension. Dissolved sucrose probably provided a cohesive form in the other solutions, and the viscosity of the carrying solution had a greater effect on the source term than total solids loading. Two additional spills of the slurry ( $500 \mathrm{~g} / \mathrm{L}$ solids) containing sucrose were conducted. The fraction of mass made airborne from each of these slurry spills was less than $5 \times 10^{-5}$ and decreased as more sucrose was added. Lowering the surface tension of a uranine solution produced a slightly higher spill source term. However, based on previous spill data, this effect may not be as significant as other characteristics of the liquid. 


\section{CONTENTS}

ABSTRACT

EXECUTIVE SUMMARY

INTRODUCTION

EXPERIMENTAL PROCEDURES

SOLUTIONS

3

Sucrose Solutions

Slurries

3

Uranine with Lower Surface Tension

4

MEASUREMENTS

4

SAMPLING IN THE RADIOACTIVE AEROSOL RELEASE TANK

6

SAMPLE ANALYSIS

7

RESULTS AND DISCUSSION

MASS AIRBORNE

9

WEIGHT PERCENT AIRBORNE

12

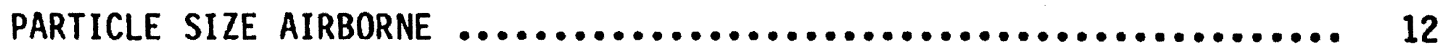

COMPARISON TO PREVIOUS RESULTS 


\section{FIGURES}

1 Morphology of Titanium Dioxide and Minus 200 Mesh

Glass Frit Particles ........................................... 5

2 Shear Stress Versus Shear Strain for Slurries 3 and $4 \ldots \ldots \ldots \ldots \ldots \ldots . . .7$

3 Sampling for a Free-Fall Spill with High-Volume Samplers ............ 8

4 Mass Airborne from Sucrose Spills ............................... 10

5 Mass Airborne from Sucrose and Slurry Spills ...................... 12

6 Weight Percent Airborne Versus Viscosity for Sucrose, Slurry, and Low Surface Tension Spills ............................. 14

\section{TABLES}

1 Components in Sucrose Solutions $\ldots \ldots \ldots \ldots \ldots \ldots \ldots \ldots \ldots \ldots \ldots \ldots \ldots \ldots \ldots \ldots . \ldots$

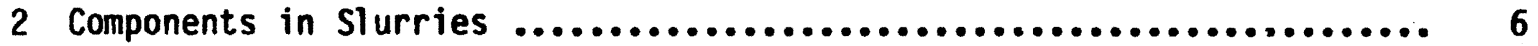

3 Average Mass Airborne from Sucrose Spills ......................... 9

4 Mass Airborne from Slurry Spills ............................... 11

5 Results of Adding Sucrose to Slurry $4 \ldots \ldots \ldots \ldots \ldots \ldots \ldots \ldots \ldots \ldots \ldots \ldots \ldots 11$

6 Weight Percent Airborne for Sucrose, Slurry, and Low Surface Tension Spills .................................... 13

7 Size Distribution of Particles Generated by Sucrose Solution Spills ........................................ 14

8 Size Distribution of Particles Generated by Slurry Spills ................................................. 15

9 Comparison of Sucrose and Slurry Spills to Previous Experiments 


\section{INTRODUCTION}

Pacific Northwest Laboratory (PNL) is developing methods for estimating airborne source terms from accidents in nuclear fuel cycle facilities. The work is sponsored by the U.S. Nuclear Regulatory Commission (NRC) in an effort to provide improved, more realistic methods for describing the quantity and characteristics of aerosols generated by major accidents in nuclear fuel cycle facilities. The need for information on spills, one of the accidents covered by this effort, was identified in a literature review. The experiments described in this report are part of a series of spill experiments conducted to provide information on aerosol source terms from spills.

During earlier experimental investigations (Sutter et al. 1981), aerosols generated by free-fall spills of powders and solutions were measured. These airborne releases are being used to develop models for estimating releases from postulated accidents involving these materials. Slurries and molten glass can also be involved in accidental spills in fuel cycle facilities, so releases from viscous solutions and slurries were studied. Solutions with varying concentrations of sucrose were spilled to determine the applicability of the liquid spill model, being developed from previous data, to solutions of higher viscosity. Slurries were also spilled to provide data for source-term models, and low surface tension solution was spilled to determine the significance of surface tension on the fraction of solution that becomes airborne.

In our previous investigations, powders were dispersed as they fell, and liquids were dispersed when they impacted surfaces. Because slurry and molten glass spills were assumed to behave in a manner similar to other liquid spills, the properties controlling liquid spills were related to similar properties of slurries and molten glass. Based on earlier models (Stow and Hadfield 1980), properties of the liquid, such as surface tension and viscosity, were thought to have a significant influence on the formation of aerosols from a liquid spill. The experiments described in this report were performed to examine the influence of surface tension and solution viscosity on the amount of airborne releases and particle-size distribution of aerosols generated from spills, and to provide exploratory data for slurry spills.

This report details the general procedures used in our investigations, followed by a discussion of the results. We used the same release vessel (i.e., the Radioactive Aerosol Release Tank [RART]), sampling procedures, and sample analysis techniques that were used in earlier work (Sutter et ai. 1981). Properties of the solutions used are given in Appendix A. Airborne mass measurements and aerodynamic mass median diameters (AMMD) are listed in Appendix B. 


\section{EXPERIMENTAL PROCEDURES}

Experiments were run using five sucrose concentrations, six slurry loadings, and one solution with the surface tension reduced to half the value of previous uranine solutions. As in earlier work (Suţter et al. 1981), these spills took place in static air in the RART, a $20-\mathrm{m}^{3}$ enclosure. Releases during the event were measured, but the time-dependent behavior of the aerosol was not investigated.

\section{SOLUTIONS}

Sucrose Solutions

Sucrose solutions were prepared by dissolving a specified quantity of sucrose in warm water, then dissolving uranine in the solution. Table 1 lists the components of each solution.

\section{Slurries}

Slurries consist of two phases: liquid and solid. High-level nuclear waste-feed slurries have a solid-phase loading of many compounds such as $\mathrm{CaCO}_{3}$, $\mathrm{FeOH}, \mathrm{NaNO}_{3}, \mathrm{AlOH}_{3}$, and other similar inorganic compounds. The exact constituents vary, but generally, from 12 to $30 \mathrm{~g} / \mathrm{L}$ soluble and insoluble compounds are loaded in the waste stream. Approximately $80 \%$ of the loading is insoluble particles with anticipated diameters of less than $10 \mu \mathrm{m}$. The waste stream is slightly concentrated by evaporation, then glass formers or frit are added. The stream is concentrated again by evaporation to a total solid loading of 100 to $500 \mathrm{~g} / \mathrm{L}[400 \mathrm{~g} / \mathrm{L}$ is ihe desired loading for the Hanford Waste Vitrification Project (HWVP)]. Glass frit or formers generally compose over $60 \%$ of the loading. Frit particles may be 50 mm and larger.

Two slurries were prepared for these experiments: one representing the waste stream before adding glass frit and other additives, and the other representing the feed stream just before vitrification. The liquid phase was an aqueous solution containing $20 \mathrm{~g} / \mathrm{L}$ of uranine. Titanium dioxide was used to simulate the insoluble fraction in the waste feed. Titanium dioxide has a

TABLE 1. Components in Sucrose Solutions

\begin{tabular}{|c|c|c|}
\hline Concentration, $\%$ & Sucrose, $\mathrm{g} / \mathrm{L}$ & Uranine, $g / L$ \\
\hline 0 & 0 & 20 \\
\hline 22 & 240 & 20 \\
\hline 40 & 480 & 20 \\
\hline 49 & 600 & 20 \\
\hline 56 & 720 & 20 \\
\hline
\end{tabular}


smaller particle size and stays suspended better than other compounds tested $\left[\mathrm{CaCO}_{3}, \mathrm{Al}(\mathrm{OH})_{3}, \mathrm{Al}_{2} \mathrm{O}_{3}\right]$. Titanium dioxide loadings of 10 and $100 \mathrm{~g} / \mathrm{L}$ were prepared representing the range of waste feed concentrations that might be encountered. (Although it has been est imated that streams may contain 12 to $30 \mathrm{~g} / \mathrm{L}$ total solids in the waste feed stream before the first evaporation step, the concentration after the first evaporation has not been reported in the open literature.) One hundred grams per liter is considered a conservative estimate of the high loading. Most of the evaporation takes place after the addition of glass formers or frit.

Two loadings of the second slurry were prepared. These loadings were 100 and $500 \mathrm{~g} / \mathrm{L}$ with $60 \%$ of the total solids provided by a minus 200 mesh glass frit (particles screened through a mesh with 200 wires per inch). Figure la and $b$ show the morphology and size of the $\mathrm{TiO}_{2}$ and glass frit particles, respectively.

Table 2 lists the components in each of the slurries. Sucrose was added in the first four slurries to inhibit settling of the solids. Fifty grams of sucrose were added at a time until 99\% of the slurry stayed suspended for 1 min--the amount of time it takes to set up the experiment and spill the solution. In the last two slurries, sucrose was added to examine the effect of a more viscous carrying solution on fraction airborne.

Uranine with Lower Surface Tension

A few drops of an anionic surfactant, Dowfax $2 A 1$, was added to lower the surface tension to slightly more than half its former value in two spills.

\section{MEASUREMENTS}

Several measurements were taken to characterize the solutions before the spill. Surface tension was measured with a tensiometer (Fisher ${ }^{\circ}$ Surface Tensiometer Model 20). Viscosity (apparent viscosity for slurries) was measured with a viscometer (Brookfield Digital Viscometer). Specific gravity and 1iquid temperature were also measured and recorded. Slurries were stirred to uniform composition before measuring.

In addition to apparent viscosity, a rotational viscometer (Haake Rotovisco RV-100) produced shear stress versus shear strain diagrams for each of the slurries. The diagrams in Figure 2 describe the rheology of the fluid

- Dowfax is a registered tradename of the Dow Chemical Company, Midland, Michigan.

- Fisher is a registered tradename of the Fisher Scientific Company, Pittsburgh, Pennsylvania.

- Brookfield is a registered tradename of the Brookfield Engineering Laboratories, Stoughton, Massachusetts.

- Haake Rotovisco is a registered tradename of Haake Inc., Saddles Brook, New Jersey. 

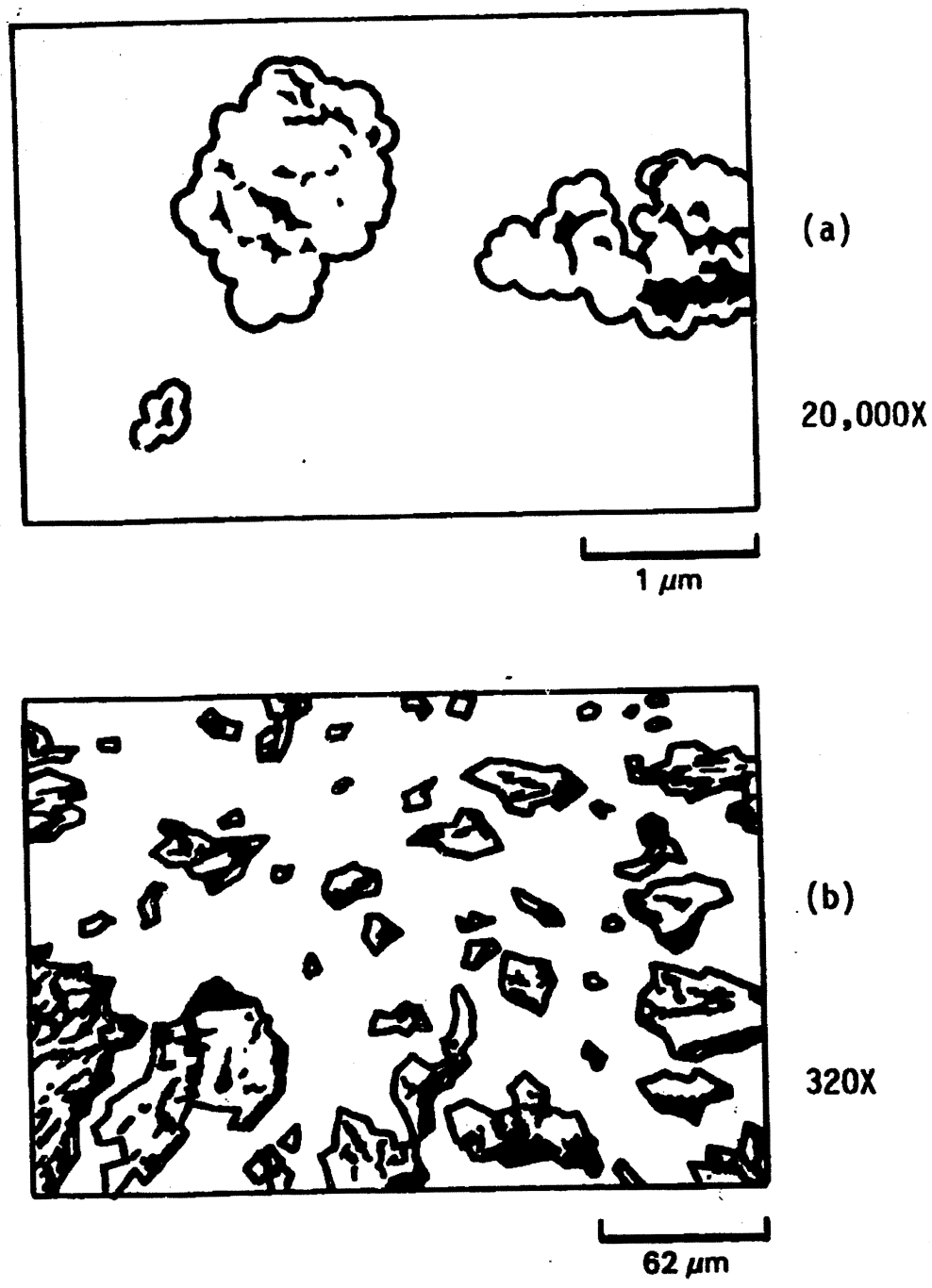

FIGURE 1. Morphology of (a) Titanium Dioxide and (b) Minus 200 Mesh Glass Frit. Particles

and show deviation from the behavior of a Newtonian fluid. Sheer stress versus sheer strain diagrams are shown for slurries 3 and 4 . Slurry 3 is a Newtonian fluid, exhibiting the straight line. Slurry 4, however, has a large offset from the origin, indicating shear stress must increase beyond one to overcome shear strain. This offset is characteristic of a Bingham plastic. The upward curve of the diagram after the offset indicates pseudoplastic behavior. All slurries, except 1 and 3 , indicated some degree of non-Newtonian behavior as seen in the figure by an offset from the origin and/or a slight curve of the line. Slurry 4 deviated the most from a Newtonian fluid. 
TABLE 2. Components in Slurries, g/L

\begin{tabular}{cccccc}
$\begin{array}{c}\text { Slurry } \\
\text { Number }\end{array}$ & $\begin{array}{c}\text { Titanium } \\
\text { Dioxide }\end{array}$ & Glass Frit & & Uranine & Sucrose \\
\cline { 1 - 2 } 1 & 10 & 0 & 0 & 20 & 250 \\
2 & 100 & 0 & 20 & 200 \\
3 & 40 & 60 & 20 & 335 \\
4 & 200 & 300 & 20 & 0 \\
5 & 200 & 300 & 20 & 100 \\
6 & 200 & 300 & 20 & 200
\end{tabular}

After the first four slurries were spilled, the quality of the carrying solution was thought to affect the source term. The viscosity of the carrying solution was measured by allowing the slurries to settle, collecting the decant, and measuring decant viscosity. Properties of sucrose solutions and slurries are given in Tables A.1 and A.2 of Appendix A, respectively.

Air temperature, relative humidity, and barometric pressures were also recorded for each experiment to characterize conditions of the air through which solutions were spilled. Four of the spills of sucrose solutions were filmed with high-speed photography.

SAMPLING IN THE RADIOACTIVE AEROSOL RELEASE TANK

The general sampling and experimental procedure used in conducting the experiments is shown in Figure 3. Following the spill of $1 \mathrm{~L}$ of solution, samplers were immediately turned on and the particle-laden air pulled through filters, as indicated by tite solid arrows in Figure 3. Clean air exited from the rear as indicated by the light arrows.

The experiments were conducted in the RART. It is a cylindrical vessel made of stainless steel, approximately $3.0 \mathrm{~m}$ high and $2.9 \mathrm{~m}$ in diameter with a $20-\mathrm{m}^{3}$ volume (about the size of a small room). The RART volume was considered when selecting the length of sampling.

High-volume filter samplers equipped with glass fiber filters were used for mass sampling; a cascade impactor was used for size-distribution samples. As in previous experiments, the samplers and impactor were located at the same levels (Figure 3): high-volume samplers at the $1-m$ and $2-m$ level, and the cascade impactor at the 1.5-m level. Eight RART volumes of air were pulled through the samplers in a 30-min run, which is the same sampling used for earlier liquid releases. 


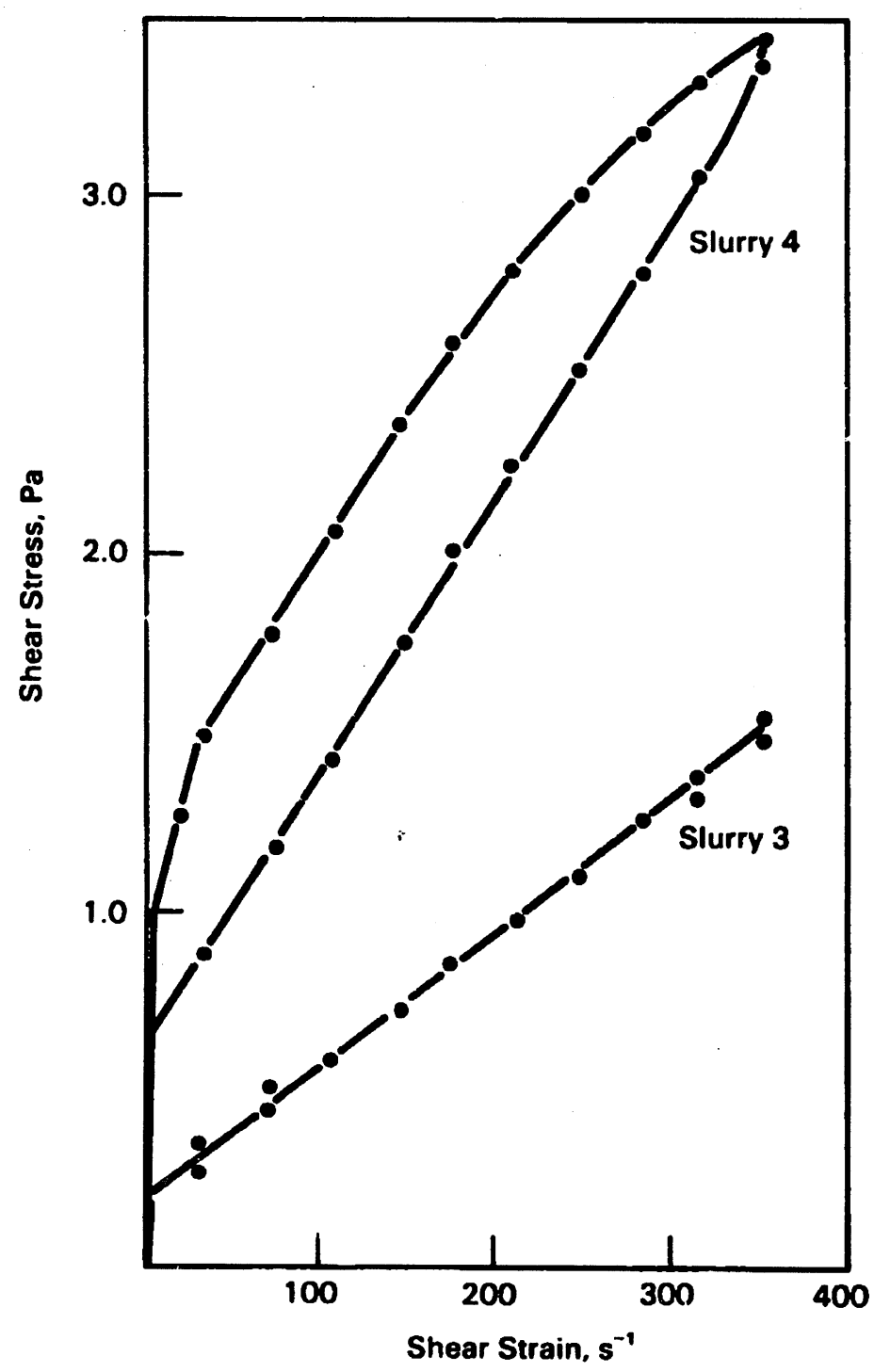

FIGURE 2. Shear Stress Versus Shear Strain for slurries 3 and 4

high-speed photography was also used during spills of the sucrose solutions to enable a better understanding of the results. These visual records confirm and help explain the data analysis results.

\section{SAMPLE ANALYSIS}

Uranine collected on the filters was dissolved in water and analyzed by fluorometry. Dilutions of a known standard stock solution representing different concentrations were made and the results read on a fluorometer. The lower detection limit is about $1 \times 10^{-9} \mathrm{~g} / \mathrm{cm}^{3}$. Equations were reformulated for the 


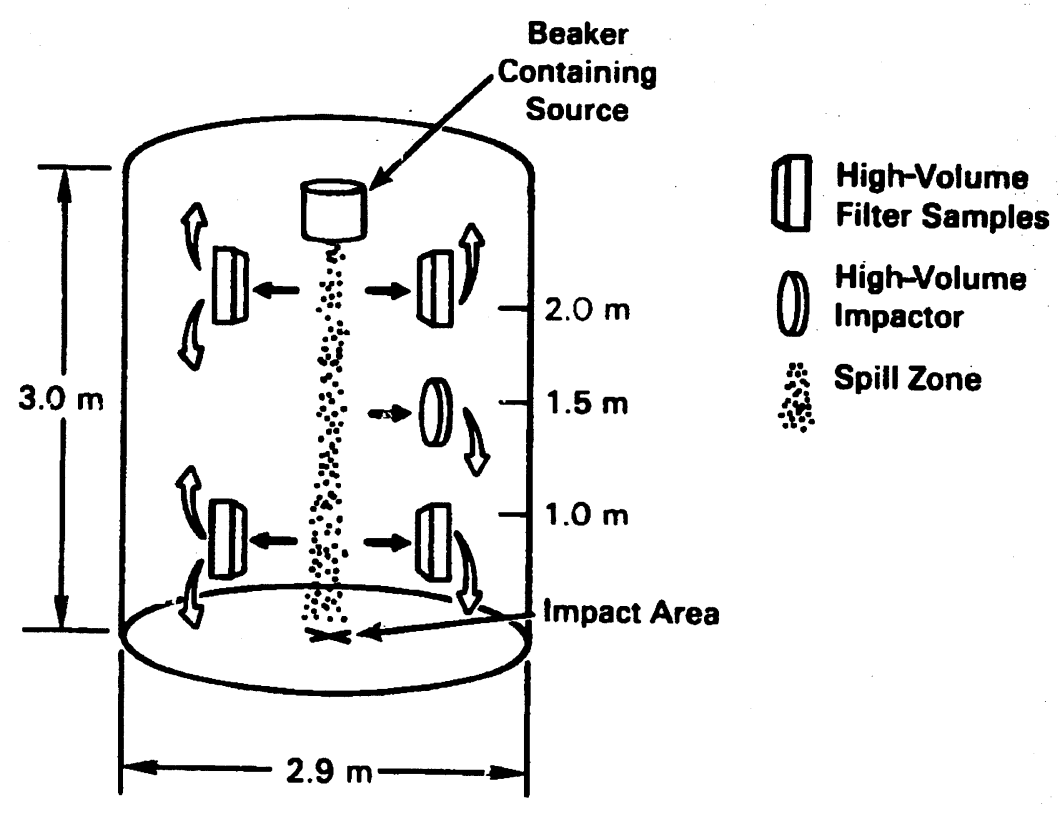

FIGURE 3. Sampling for a Free-Fall Spill with High-Volume Samplers

measured values at each of the four fluorometer ranges and used for calculating results. $R^{2}$ (correlation between observed and predicted values) values approached one, indicating a good fit for the standards.

An attempt was made to separate the airborne solids from the solution in the slurry spills. The uranine was separated from the filters in these experiments by gently rinsing the filters with water. Filters were then oven dried and weighed. This weight was compared to the filter weight before the experiment to determine the change in weight attributable to both airborne solids retained on the filter and filter changes from the rinsing and drying procedure. The change in weight came from weight lost solely from rinsing and drying. No airborne solids were detected in any of the experiments. 
RESULTS AND DISCUSSION

Included in the following discussion are results of the high-volume sampling of the sucrose, slurry, and low surface tension spills. These results will be used to develop models that will estimate airborne releases of accident-generated aerosols. These models, which are to be based on physical parameters, will be described in a later report.

Appendix B contains a complete listing of the measured release and particle-size data.

\section{MASS AIRBORNE}

Averages of the mass of uranine airborne from the sucrose spills are shown in Table 3. (For values of individual experiments, see Appendix B.) This table also shows the average value of the properties of the viscous solutions spilled. Although the purpose of this set of experiments was to determine the effect of increased viscosity on the source term, surface tension and density also increased as the sucrose concentration inc eased. The three physical parameters are interrelated, and increases in all three cause a decrease in mass airborne. Since the percent increase in surface tension and specific gravity is slight compared to the percent increase in viscosity, the assumption is made that a decrease in mass airborne is mainly due to increase in viscosity. Figure 4 is a plot of mass airborne versus viscosity on a log-log scale. A regression line through the data has a coefficient of determination $(R)$ of 0.962 . Values close to one indicate a strong correlation.

The slurry experiments provided exploratory data for slurry spills. Although slurries have both a liquid and solid phase, during the spill they were expected to behave in a manner similar to previous liquid spills. Characteristics of the slurry [solid loading, flow properties (as measured by a rotational viscometer), and composition] were also expected to influence the

\section{TABLE 3. Average Mass Airborne from Sucrose Spills}

\begin{tabular}{|c|c|c|c|}
\hline $\begin{array}{c}\text { Mass } \\
\text { Airborne, } \\
\text { mg } \\
\end{array}$ & $\begin{array}{c}\text { Viscosity, } \\
\mathrm{cp}\end{array}$ & $\begin{array}{l}\text { Surface } \\
\text { Tension, } \\
\text { dynes/cm }\end{array}$ & $\begin{array}{l}\text { Specific } \\
\text { Gravity } \\
\end{array}$ \\
\hline 518 & 1.3 & 65.2 & 1.01 \\
\hline 156 & 2.6 & 68.9 & 1.10 \\
\hline 85 & 7.9 & 70.9 & 1.19 \\
\hline 41 & 17.5 & 77.4 & 1.23 \\
\hline 33 & 46.0 & 74.5 & 1.28 \\
\hline
\end{tabular}




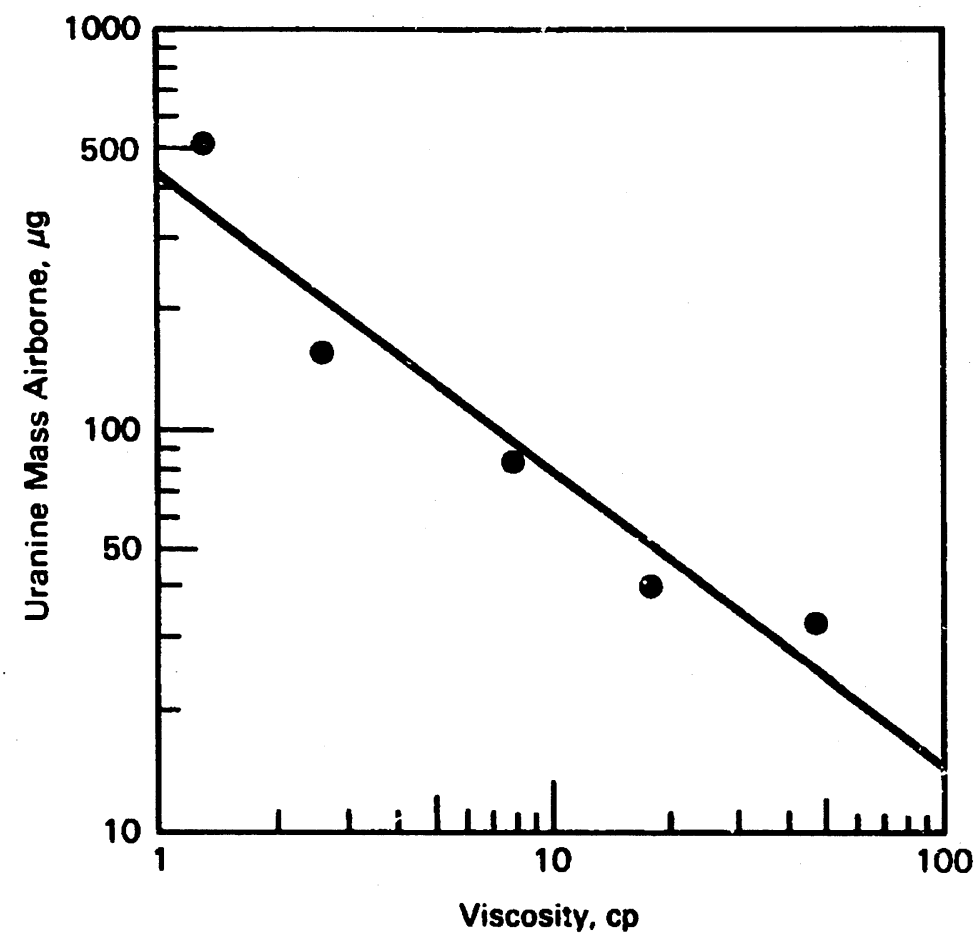

FIGURE 4. Mass Airborne From Sucrose Spills

source term. These characteristics were varied to determine their impact on the fraction airborne and particle-size distribution from slurry spills.

The mass airborne of the first six experiments are shown in Table 4. Two replicates were included in the series and show a high experimental variability (see Appendix B for values of individual runs). Contrary to expectations, the largest amount airborne came from the slurry with the highest solids loading (slurry 4). This slurry was also the only one in which no sucrose was required to increase solid suspension. The sucrose added to the other slurries probably acted as a cohesive force in the carrying solution, keeping it from subdividing during the spill into fine droplets, which are more easily suspended. To test this theory, two additional experiments were run in which slurry 4 with sucrose was spilled (Table 5). As can be seen in this table, the mass airborne from the spills decreased slightly as the sucrose content (and viscosity of the slurry decant) increased.

Slurry spills exhibited behavior similar to that of sucrose spills. In both cases, viscosity of the liquid has a significant impact on mass airborne. Both sets of data are plotted in Figure 5 . The $R$ value for a regression line through the data dropped slightly to 0.960 . 
TABLE 4. Mass Airborne from Slurry Spills

\begin{tabular}{lrrrrr} 
& \multicolumn{4}{c}{ Slurry } & Number \\
\cline { 2 - 5 } Mass Airborne, 106 & 146 & & $\frac{2}{3}$ & $\frac{3}{206}$ & $\frac{4}{706}$ \\
Titanium Dioxide, $\mathbf{g}$ & 10 & 100 & 40 & 200 \\
Glass frit, g & 0 & 0 & 60 & 300 \\
Sucrose, g & 250 & 200 & 335 & 0 \\
Total solids, wt\% & 25 & 28 & 38 & 39 \\
Soluble Solids, wt\% & 25 & 19 & 30 & 1.5 \\
Viscosity, CP & NM(a) & NM & 3.1 & 1.3
\end{tabular}

(a) Not measured.

TABLE 5. Results of Adding Sucrose to Slurry 4

\begin{tabular}{lrrr} 
& \multicolumn{3}{c}{ Slurry Number } \\
\cline { 2 - 4 } Titanium oxide, g & $\frac{4}{5}$ & $\frac{6}{5}$ & $\frac{200}{200}$ \\
Glass frit, g & 300 & 300 & 300 \\
Sucrose, g & 0 & 100 & 200 \\
Soluble solids, wt\% & 2 & 9 & 16 \\
Decant viscosity, cp & 1.3 & 1.3 & 2.9 \\
Mass Airborne, 106 & 706 & 412 & 308
\end{tabular}

To examine the effect of surface tension alone on the source term, a surface tension-lowering compound was added to a uranine solution. Surface tension was lowered to 33.3 dynes $/ \mathrm{cm}$, while viscosity and specific gravity were maintained at $1.2 \mathrm{cp}$ and $1.00 \mathrm{~g} / \mathrm{cm}^{3}$, respectively. The average mass airborne from this spill and a replicate was $384 \mu \mathrm{g}$. The mass airborne from similar spills with high surface tension $(65.2$ dynes $/ \mathrm{cm})$ was $518 \mu \mathrm{g}$. However, the low surface tension spill was less concentrated with uranine. The average fraction airborne from the low and high surface tension spills was $4.2 \times 10^{-5}$ and $3.0 \times 10^{-5}$, respectively. Thus, lowering the surface tension may increase the fraction airborne from spills. 


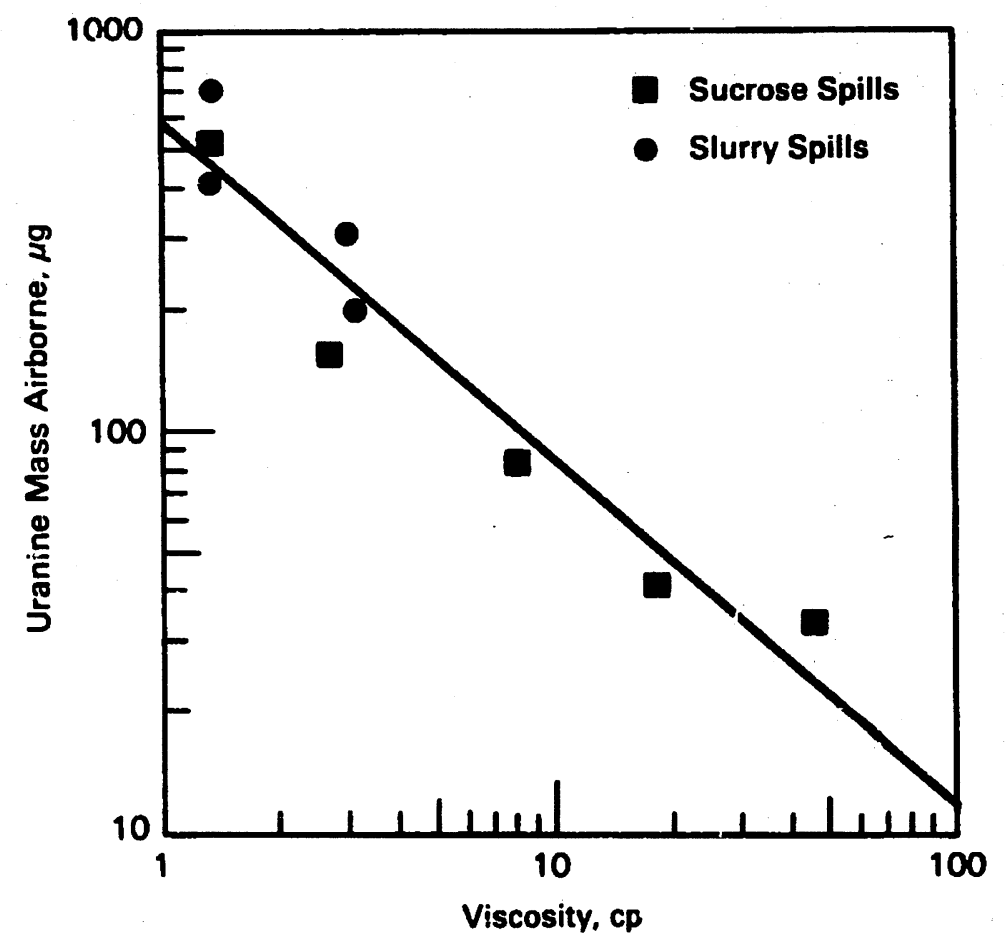

FIGURE 5. Mass Airborne from Sucrose and Slurry Spills

\section{WEIGHT PERCENT AIRBORNE}

Properties of the liquid and weight percent airborne for the sucrose, slurry, and low surface tension spills are listed in Table 6. Data are grouped according to viscosity and weight percent airborne. A graph of weight percent airborne versus viscosity for these data is shown in Figure 6 . A regression line drawn through the data has an $R$ value of 0.9669 , which indicates a good fit.

\section{PARTICLE SIZE AIRBORNE}

Particles that become airborne from spilling viscous solutions tended to be slightly smaller at higher viscosities as shown in Table 7. Less stress was required to subdivide the lower viscosity liquids, thus larger particles could be made more easily. Table 8 shows the (average) median diameter of particles generated by slurry spills (see Appendix B for values for individual runs). Size appears to be independent of slurry properties.

The average median diameter and geometric standard deviation of aerosols produced by low surface tension spills are 4.2 and 7.0 , respectively. This size corresponds to that of the sucrose solutions at low viscosity. Data are not available to determine the effect of surface tension on aerosol particle size. 
TABLE 6. Weight Percent Airborne for Sucrose, Slurry, and Low Surface Tension Spills

\begin{tabular}{|c|c|c|c|c|}
\hline Spill & $\begin{array}{l}\text { Weight Percent } \\
\text { Airborne } \times 10^{4} \\
\end{array}$ & $\begin{array}{c}\text { Viscosity, } \\
\text { cp } \\
\end{array}$ & $\begin{array}{l}\text { Surface } \\
\text { Tension, } \\
\text { dynes/cm }\end{array}$ & $\begin{array}{l}\text { Specific } \\
\text { Gravity } \\
\end{array}$ \\
\hline \multirow[t]{5}{*}{ Sucrose } & 30.1 & 1.3 & 65.2 & 1.01 \\
\hline & 9.2 & 2.6 & 68.9 & 1.10 \\
\hline & 4.8 & 7.9 & 70.9 & 1.19 \\
\hline & 2.4 & 17.5 & 77.4 & 1.23 \\
\hline & 2.0 & 46.0 & 74.5 & 1.28 \\
\hline \multirow[t]{6}{*}{ Slurry } & 36.6 & 1.3 & 63.3 & 1.34 \\
\hline & 30.2 & 1.3 & 64.9 & 1.29 \\
\hline & 16.0 & 2.9 & 62.8 & 1.41 \\
\hline & 13.4 & 3.1 & 66.5 & 1.20 \\
\hline & 11.0 & $N M(a)$ & 54.5 & 1.16 \\
\hline & 8.7 & 3.2 & 58.2 & 1.12 \\
\hline $\begin{array}{l}\text { Low Surface } \\
\text { Tension }\end{array}$ & 41.5 & 1.2 & 33.3 & 1.00 \\
\hline
\end{tabular}

(a) Not measured.

Particle-size distributions were measured using the cascade impactor samples and may not represent the actual size distribution of airborne liquid droplets. Significant evaporation and settling of the droplets before they are captured in the impactor could mean that the measured size distribution does not correspond to that of the actual airborre aerosol. This problem will be handled during model development and will be discussed in the modeling report.

\section{COMPARISON TO PREVIOUS RESULTS}

Table 9 compares the results of the sucrose, slurry, and low surface tension spills to previous spills of powders (depleted uranium dioxide and $\mathrm{TiO}_{2}$ at a 3-m height) and riquids ( 1 L uranyl nitrate hexahydrate and uranine at a $3-m$ height) (Sutter et al. 1981). The greatest fraction airborne and largest AMMD from the slurry and sucrose spills are similar to the lowest fraction airborne and smallest AMM from the previous liquid spills. 


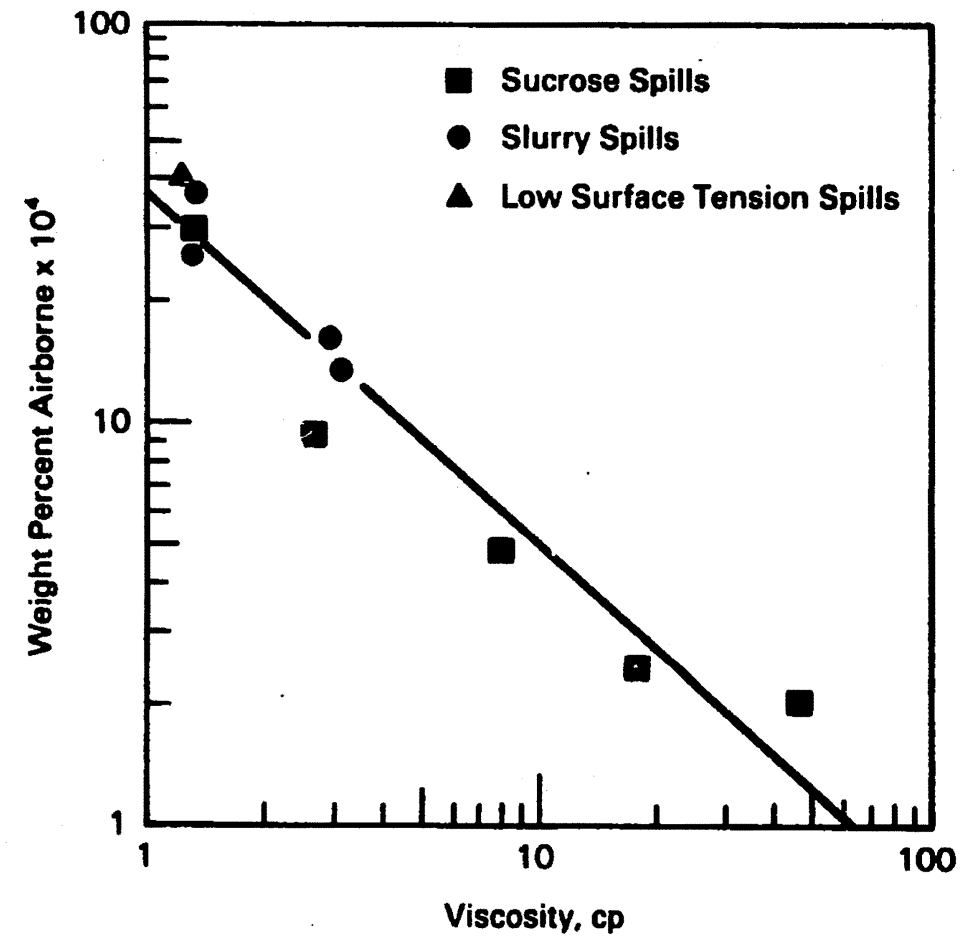

FIGURE 6. Weight Percent Airborne Versus Viscosity for Sucrose, Slurry, and Low Surface Tension Spills

TABLE 7. Size Distribution of Particles Generated by Sucrose Solution Spills

\begin{tabular}{|c|c|}
\hline $\begin{array}{c}\text { Viscosity, } \\
\mathrm{CP}\end{array}$ & $\begin{array}{c}\text { Median } \\
\text { Diameter, } \mu \mathrm{g} \\
\end{array}$ \\
\hline 1.3 & 5.7 \\
\hline 2.6 & 3.8 \\
\hline 7.9 & 1.1 \\
\hline 17.5 & 1.9 \\
\hline 46.0 & 1.3 \\
\hline
\end{tabular}


TABLE 8. Size Distribution of Particles Generated by Slurry Spills

\begin{tabular}{|c|c|}
\hline $\begin{array}{c}\text { Viscosity, } \\
C P\end{array}$ & $\begin{array}{c}\text { Median } \\
\text { Diameter, } \mu \mathrm{g} \\
\end{array}$ \\
\hline$M M(a)$ & 2.3 \\
\hline NM & 4.7 \\
\hline 3.1 & 2.3 \\
\hline 1.3 & 3.1 \\
\hline 1.3 & 2.6 \\
\hline 2.9 & 4.7 \\
\hline
\end{tabular}

(a) Not measured.

TABLE 9. Comparison of Sicrose and Slurry Spills to Previous Experiments

\begin{tabular}{|c|c|c|}
\hline & $\begin{array}{c}\text { Fract.ion } \\
\text { Airborne, } \times 10^{6} \\
\end{array}$ & $\begin{array}{c}\text { Aerodynamic } \\
\text { Mass Median } \\
\text { Diameter, } \\
\text { micror. } \\
\end{array}$ \\
\hline Powder, $3 \mathrm{~m}$ & $200-11,900$ & $3-36$ \\
\hline Liquid, $3 \mathrm{~m}, 1 \mathrm{~L}$ & $44-128$ & $7-32$ \\
\hline Sucrose & $2-30$ & $1-7$ \\
\hline Slurry & $9-46$ & $2-5$ \\
\hline Low Surface Tension & $38-45$ & $4-5$ \\
\hline
\end{tabular}

$15 \mid 16$ 


\section{REFERENCES}

Stow, C. D. and M. G. Hadfield. 1980. "An Investigation of the Condition for Splashing of Water Drops on Solid, Dry Surfaces." J. Meteorol. Soc. of Japan 58:59-68.

Sutter, S. L., J. W. Johnston and J. Mishima. 1981. Aerosols Generated by Free Fall Spills of Powders and Solutions in Static Air. NUREG/CR-2651, U.S. Nuclear Regulatory Commission, Washington, D.C. 
APPENDIX A

SOLUTION PROPERTIES 
APPENDIX A

SOLUTION PROPERTIES

TABLE A.1. Properties of Sucrose Solutions

\begin{tabular}{|c|c|c|c|}
\hline $\begin{array}{l}\text { Concentration, } \\
\text { percent sucrose }\end{array}$ & $\begin{array}{c}\text { Viscosity, } \\
C P\end{array}$ & $\begin{array}{c}\text { Surface Tension, } \\
\text { dynes } / \mathrm{cm}\end{array}$ & $\begin{array}{l}\text { Specific } \\
\text { Gravity } \\
\end{array}$ \\
\hline 0 & 1.3 & 63.3 & 1.005 \\
\hline 0 & 1.3 & 67.0 & 1.005 \\
\hline 22 & 2.6 & 68.5 & 1.102 \\
\hline 22 & 2.5 & 69.3 & 1.101 \\
\hline 40 & 8.0 & 70.9 & 1.188 \\
\hline 40 & 7.9 & 70.8 & 1.191 \\
\hline 49 & 17.2 & 83.0 & 1.233 \\
\hline 49 & 17.7 & 71.8 & 1.235 \\
\hline 56 & 47.1 & 73.2 & 1.277 \\
\hline 56 & 44.9 & 75.7 & 1.276 \\
\hline
\end{tabular}

TABLE A.2. Properties of Slurries

Run Slurry Weight Percent Solids Specific Surface Tension, Viscosity of Number Number Total Soluble (a) Gravity

$\begin{array}{ccc}\text { dynes/cm } & & \text { Decant, } c p \\ 58.2 & & 3.2 \\ 64.5 & \mathrm{NM}(\mathrm{b}) \\ 68.4 & & 4.9 \\ 63.1 & & 3.1 \\ 63.4 & & 1.3 \\ 64.9 & & 1.3 \\ 62.8 & & 2.9\end{array}$

(a) Uranine and sucrose.

(b) Not measured. 
TABLE A.3. Properties of Uranine with Dowfax $2 A 1$

\begin{tabular}{ccc}
$\begin{array}{c}\text { Viscosity, } \\
\text { cp }\end{array}$ & $\begin{array}{c}\text { Surface Tension, } \\
\text { dynes/cm }\end{array}$ & $\begin{array}{c}\text { Specific } \\
\text { Gravity }\end{array}$ \\
\cline { 1 - 1 } 1.14 & 33.3 & 1.004 \\
1.24 & 33.3 & 1.004
\end{tabular}

A.2 


\section{APPENDIX B}

EXPERIMENTAL DATA 
APPENDIX B

EXPER IMENTAL DATA

TABLE B.1. Mass Airborne from Sucrose Solution Spills

( source volume $=1 \mathrm{~L}$, source height $=3 \mathrm{~m}$ )

$\begin{array}{ccccc}\begin{array}{c}\text { Concentration, } \\ \text { percent sucrose }\end{array} & \begin{array}{c}\text { Uranine } \\ \text { Collected, mg }\end{array} & \begin{array}{c}\text { Total Solution } \\ \text { Airborne, mg }\end{array} & \begin{array}{c}\text { Measured Weight Percent } \\ \text { Airborne } \times 10^{4}\end{array} \\ 0 & 0.54 & 32.4 & 32.2 \\ 22 & 0.49 & 23.2 & 28.0 \\ 22 & 0.12 & 8.0 & 7.3 \\ 40 & 0.19 & 12.2 & 11.1 \\ 40 & 0.07 & 4.6 & 3.8 \\ 49 & 0.10 & 6.8 & 5.7 \\ 49 & 0.05 & 3.4 & 2.7 \\ 56 & 0.04 & 2.7 & 2.1 \\ 56 & 0.03 & 2.0 & 1.6 \\ & 0.04 & 3.0 & 2.3\end{array}$

TABLE B.2. Size of Particles Produced by Sucrose Solution Spills

\begin{tabular}{|c|c|c|c|c|}
\hline $\begin{array}{l}\text { Concentration, } \\
\text { percent sucrose }\end{array}$ & $\begin{array}{l}\text { Aerodynamic } \\
\text { Mass Median } \\
\text { Diameter, Hm } \\
\end{array}$ & $\sigma_{g}$ & $\begin{array}{l}\text { Percent } \\
\leq 10 \mu \mathrm{m} \\
\end{array}$ & $\begin{array}{l}\text { Measured } \\
\text { Weight Percent } \\
\text { Airborne } \times 10^{4} \\
\text { that is }<10 \mu \mathrm{m}\end{array}$ \\
\hline 0 & 7.0 & 5.8 & 59 & 19.0 \\
\hline 0 & 4.3 & 7.2 & 74 & 20.7 \\
\hline 22 & 4.8 & 7.7 & 70 & 5.1 \\
\hline 22 & 2.7 & 7.5 & 76 & 8.4 \\
\hline 40 & 1.6 & 10.0 & 80 & 3.0 \\
\hline 40 & 0.6 & 28.0 & 83 & 4.7 \\
\hline 49 & 2.2 & 5.5 & 78 & 2.1 \\
\hline 49 & 1.6 & 4.6 & 90 & 1.9 \\
\hline 56 & 1.9 & 7.7 & 84 & 1.3 \\
\hline 56 & 0.6 & 10.0 & 89 & 2.0 \\
\hline
\end{tabular}

B.1 
TABLE B.3. Mass Airborne from Slurry Spills (source volume $=1 \mathrm{~L}$, height $=3 \mathrm{~m}$ )

\begin{tabular}{|c|c|c|c|}
\hline $\begin{array}{l}\text { Slurry } \\
\text { Number }\end{array}$ & $\begin{array}{l}\text { Uranine } \\
\text { Collected, mg (a) } \\
\end{array}$ & $\begin{array}{l}\text { Total Solution } \\
\text { Airborne, mg } \\
\end{array}$ & $\begin{array}{c}\text { Measured } \\
\text { Weight Percent } \\
\text { Airborne } \\
\end{array}$ \\
\hline 1 & $0.15^{(a)}$ & 9.8 & 0.0009 \\
\hline 2 & $0.20^{(a)}$ & 12.7 & 0.0011 \\
\hline 3 & 0.14 & 10.9 & 0.0009 \\
\hline 3 & 0.27 & 21.1 & 0.0018 \\
\hline 4 & 0.85 & 61.4 & 0.0046 \\
\hline 4 & 0.57 & 36.6 & 0.0027 \\
\hline 5 & 0.41 & 32.2 & 0.0030 \\
\hline 6 & 0.31 & 22.5 & 0.0016 \\
\hline
\end{tabular}

(a) One of the filters dropped to the floor and became contaminated. Based on the other runs it was assumed that $23 \%$ of the total mass would have come from this filter.

TABLE B.4. Size of Particles Produced by Slurry Spills

\begin{tabular}{|c|c|c|c|c|}
\hline $\begin{array}{l}\text { Slurry } \\
\text { Number }\end{array}$ & $\begin{array}{l}\text { Aerodynamic } \\
\text { Mass Median } \\
\text { Diameter, } \mu \mathrm{m} \\
\end{array}$ & $\sigma_{g}$ & $\begin{array}{l}\text { Percent } \\
\leq 10 \mu \mathrm{m} \\
\end{array}$ & $\begin{array}{l}\text { Measured } \\
\text { Weight Percent } \\
\text { Airborne } \times 10^{4} \\
\text { that is }<10 \mu \mathrm{m}\end{array}$ \\
\hline 1 & 2.3 & 8.0 & 73 & 0.0027 \\
\hline 2 & 4.7 & 6.1 & 64 & 0.0007 \\
\hline 3 & 2.1 & 7.1 & 77 & 0.0007 \\
\hline 3 & 2.5 & 8.4 & 76 & 0.0014 \\
\hline 4 & 3.0 & 3.8 & 78 & 0.0036 \\
\hline 4 & 3.1 & 5.6 & 81 & 0.0022 \\
\hline 5 & 2.6 & 7.8 & 78 & $0 . .023$ \\
\hline 6 & 4.7 & 6.9 & 72 & 0.0012 \\
\hline
\end{tabular}


TABLE B.5. Mass Airborne from Low Surface Tension Spills

(source volume $=1 \mathrm{~L}$, source height $=3 \mathrm{~m}$ )

$\begin{array}{ccc}\begin{array}{c}\text { Uranine } \\ \text { Collected, mg }\end{array} & \begin{array}{c}\text { Total Solution } \\ \text { Airborne, mg }\end{array} & \begin{array}{c}\text { Measured } \\ \text { Weight Percent } \\ \text { Airborne } \times 10^{4}\end{array} \\ 0.36 & 38.2 & 38.1 \\ 0.41 & 45.0 & 44.8\end{array}$

TABLE B.6. Size of Particles Produced by Low Surface Tension Spills

Aerodynamic

Mass Median

Diameter, $\mu \mathrm{m}$

3.8

$\frac{\sigma_{g}}{7.8}$

Percent

$\leq 10 \mu \mathrm{m}$

4.5

5.2

67

Measured

Weight Percent

Airborne $\times 10^{4}$

that is $510 \mu \mathrm{m}$

25.5

33.2

B.3 


\section{DISTRIBUTION}

No. of

Copies

OFFSITE

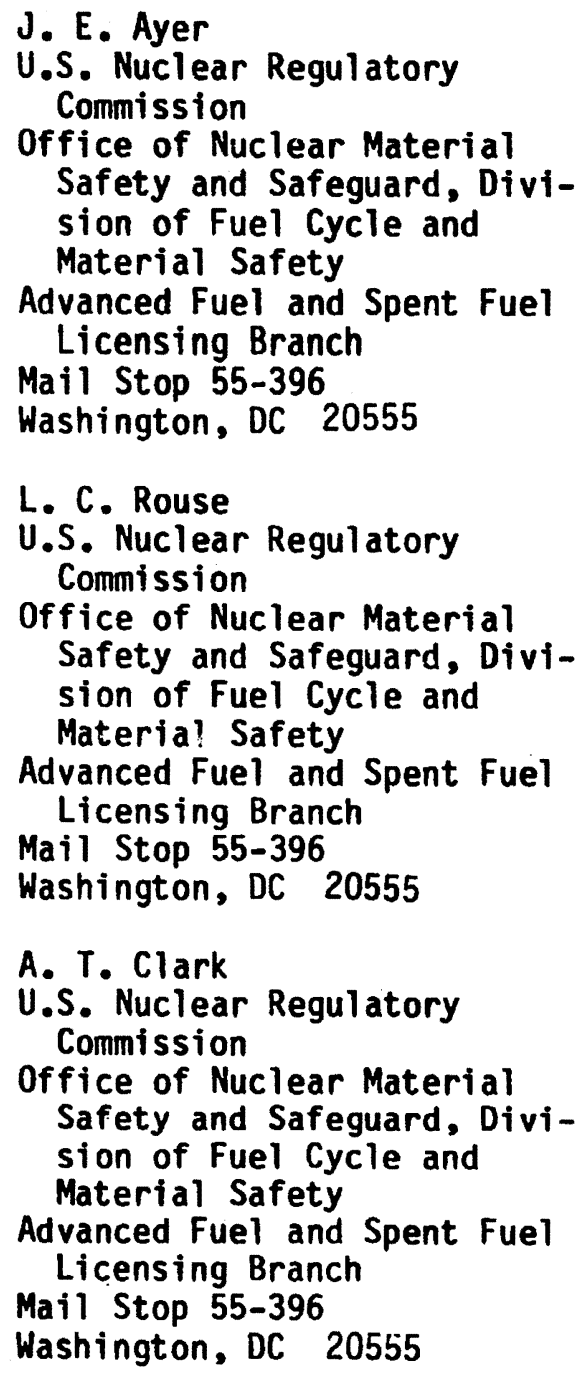

No. of

Copies

\author{
P. Loysen \\ U.S. Nuclear Regulatory \\ Commission \\ Office of Nuclear Material \\ Safety and Safeguard, Divi- \\ sion of Fuel Cycle and \\ Material Safety \\ Advanced Fuel and Spent Fuel \\ Licensing Branch \\ Mail Stop 55-396 \\ Washington, DC 20555 \\ U.S. Nuclear Regulatory \\ Commission \\ Office of Nuclear Reactor \\ Regulation \\ Division of Systems Integration \\ Accident Evaluation Branch \\ Mail Stop P-802 \\ Washington, DC 20555 \\ U.S. Nuclear Regulatory \\ Commission \\ Division of Technical \\ Information and Document \\ Control \\ 7920 Norfolk Avenue \\ Bethesda, MD 20014 \\ W. S. Gregory \\ Los Alamos National Laboratory \\ P.0. Box 1663 \\ Los Alamos, NM 87545 \\ B. D. Nichols \\ Los Alamos National Laboratory \\ P.0. Box 1663 \\ Los Alamos, NM 87545
}


No. of

Copies

M. Simen-Tov

Martin Marietta Energy Systems, Inc.

Oak Ridge National Laboratory

Process Engineering

P.0. Box $X$

Oak Ridge, TN 37831

W. R. Williams

Martin Marietta Energy Systems, Inc.

Oak Ridge National Laboratory

Process Engineering

P.0. Box $X$

Oak Ridge, TN 37831
No. of

Copies

ONSITE

36 Pacific Northwest Laboratory

M. Y. Ballinger (10)

D. W. Dragnich

C. E. Elderkin

J. J. Fuquay

J. M. Hales

P. C. Hays

W. H. Hodgson (2)

N. S. Laulainen

J. Mi shima

P. C. Owczarski (5)

D. R. Simpson

J. A. Stottlemyre

S. L. Sutter

R. E. Wildung

R. K. Woodrufi

Publishing Coordination (2)

Technical Library (5) 


\begin{tabular}{|c|c|}
\hline 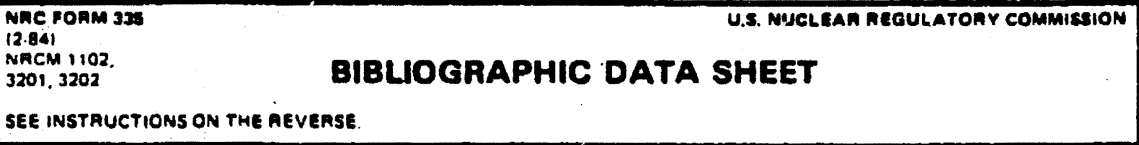 & $\begin{array}{r}\text { NUREG/CR }-4658 \\
\text { PNL }-5910\end{array}$ \\
\hline \multirow{3}{*}{$\begin{array}{l}\text { 2. TITLE AND SUSTITLE } \\
\text { Aerosols Generated by Spills of } \\
\text { Viscous Solutions and Slurries }\end{array}$} & \multirow[t]{2}{*}{ 3. LEAVE QLANK } \\
\hline & \\
\hline & 4 DATE AEPOAT COMPLETED \\
\hline \multirow{3}{*}{$\begin{array}{l}\text { S. AUTHOA(S) } \\
\text { M. Y. Ballinger } \\
\text { W. Hodgson }\end{array}$} & \begin{tabular}{c|c} 
MONTH & YEAR \\
November & 1986
\end{tabular} \\
\hline & 6. OATE REPOAT ISSUED \\
\hline & \begin{tabular}{c|c} 
MONTH & YEAR \\
December & 1986
\end{tabular} \\
\hline \multirow{2}{*}{ 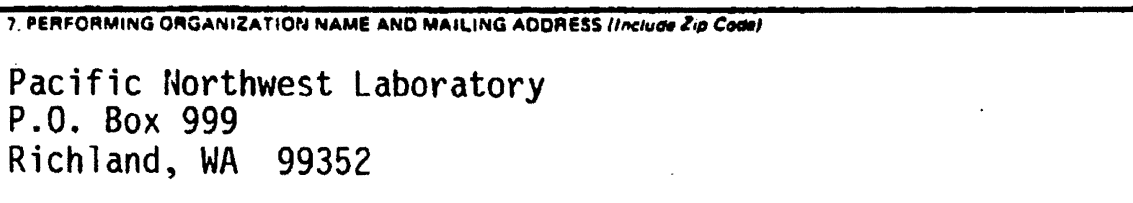 } & B.PAOJECT/TASK/WOAK UNIT NUMEEA \\
\hline & Fin $B 2481$ \\
\hline 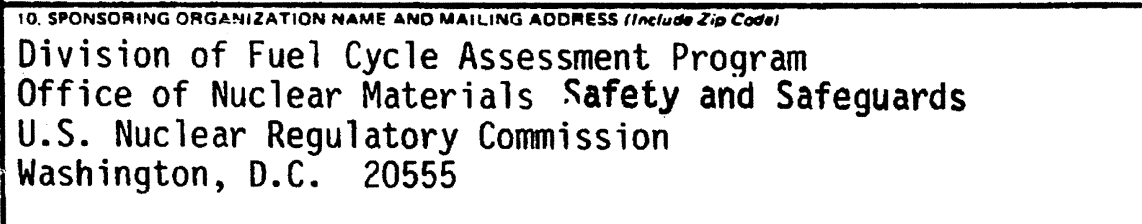 & $\begin{array}{l}\text { 11. TYPE OF AEPOAT } \\
\text { Final. }\end{array}$ \\
\hline \multicolumn{2}{|l|}{ 12. SUPP:.EMENTAAY NOTES } \\
\hline \multirow{2}{*}{\multicolumn{2}{|c|}{$\begin{array}{l}\text { Safety assessments and environmental impact statements for nuclear fuel cycle facilities } \\
\text { require an estimate of potential airborne releases caused by accidents. Aerosols generated } \\
\text { by accidents are being investigated by Pacific Northwest Laboratory to develop methods for } \\
\text { estimating source terms from these accidents. Experiments were run by spilling viscous } \\
\text { solutions and slurries to determine the mass and particle-size distribution of the material } \\
\text { made airborne. In all cases, } 1 \text { L of solution was spilled from a height of } 3 \text { m. Aqueous } \\
\text { solutions of sucrose (0 to } 56 \% \text { gave a range of viscosities from } 1.3 \text { to } 46 \text { cp. The percent } \\
\text { of spill mass made airborne from the spills of these solutions ranged from } 0.001 \text { to } 0.0001 . \\
\text { The mass of particles made airborne decreased as solution viscosity increased. Slurry } \\
\text { loading ranged from } 25 \text { to } 51 \% \text { total solids. The maximum source airborne (0.0046 wt\%) oc- } \\
\text { curred with the slurry that had the lightest loading of soluble solids. The viscosity of } \\
\text { the carrying solution also had an impact on the source term from spilling slurries. The } \\
\text { effect of surface tension on the source term was examined in two experiments. Surface ten- } \\
\text { sion was halved in these spills by adding a surfactant. The maximum weight percent air- } \\
\text { borne from these spills was } 0.0045 \text {, compared to } 0.003 \text { for spills with twice the surface } \\
\text { tension. The aerodynamic mass medium diameters for the aerosols produced by spills of the } \\
\text { viscous solutions, slurries, and low surface tension liquids ranged from } 0.6 \text { to } 8.4 \mu m \text {, } \\
\text { and the geometric standard deviation ranged from } 3.8 \text { to } 28.0 \text {. }\end{array}$}} \\
\hline & \\
\hline \multirow[t]{4}{*}{$\begin{array}{l}\text { 14. DOCUMENT ANALYSIS - KEYWORDSIOESCAIPTORS } \\
\text { Aerosols, Spills, Slurries, Viscous Solutions }\end{array}$} & $\begin{array}{l}\text { 15. AVALATLITITY } \\
\text { STATEMENT } \\
\text { Unlimited }\end{array}$ \\
\hline & 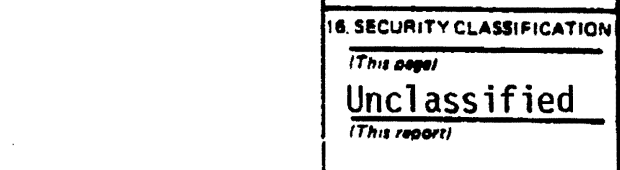 \\
\hline & 17. NUMBEA OF PACES \\
\hline & \\
\hline
\end{tabular}

